\title{
Accommodating Climate Change Science: James Hansen and the Rhetorical/Political Emergence of Global Warming
}

\section{Richard D. Besel}

California Polytechnic State University

E-mail: rbesel@calpoly.edu

\section{Argument}

Dr. James Hansen's 1988 testimony before the U.S. Senate was an important turning point in the history of global climate change. However, no studies have explained why Hansen's scientific communication in this deliberative setting was more successful than his testimonies of 1986 and 1987. This article turns to Hansen as an important case study in the rhetoric of accommodated science, illustrating how Hansen successfully accommodated his rhetoric to his non-scientist audience given his historical conditions and rhetorical constraints. This article (1) provides a richer explanation for the rhetorical/political emergence of global warming as an important public policy issue in the United States during the late 1980s and (2) contributes to scholarly understanding of the rhetoric of accommodated science in deliberative settings, an often overlooked area of science communication research.

Standing on the promontory of the rocky rims in Billings, Montana, there is usually a distinct horizontal line between the clear, blue sky and the white, snowcapped Beartooth Mountains. But the summer of 1988 was different. A fuzzy, reddish tint lingered across the once pristine skyline of "Big Sky Country." The reason: More than one hundred miles to the south, Yellowstone National Park smoldered in one of the most devastating forest fires of the twentieth century (Anon. 1988, A18; Stevens 1999, 129-130). But that was not the only thing about 1988 that was extraordinary: New York and Washington D.C. consistently saw the mercury rise to more than 100 degrees Fahrenheit, America's breadbasket experienced droughts reminiscent of the 1930s Dust Bowl, and the water level of the mighty Mississippi River sank to an all-time low. Across the United States it seemed that there were ominous warnings of accelerated global climate change.

In June of the same year, members of the U.S. Senate's Committee on Energy and Natural Resources gathered in a meeting that would thrust global climate change into the public spotlight. According to the committee's chair, Senator Timothy E. Wirth (D-CO), the purpose of the committee meeting was to "figure out how to deal with this emergency" (U.S. Congress 1988, 1). In his opening statement, Wirth recognized the importance of climate change for public policy: "In the last week many of us have 
been seeing firsthand the effects of the drought that is occurring across the heart of the country" and "as drought conditions have clearly demonstrated, those considerations stretch across the public policy spectrum" (ibid., 5). The committee's Senators were well aware of the weather conditions. Senator Kent Conrad (D-ND) said the land in his state looked like a "moonscape" because of the drought (ibid., 31). Senator Dale Bumpers (D-AR) put the scorching heat of the year, and the entire decade, into perspective: "And now we know that the four warmest years in the last 130 years - the four hottest years of the last 130 years - have occurred since 1980" (ibid., 38). However, the unusual weather was not the only reason 1988 was to be remembered. For the first time, global climate change became a significant public and policy concern in the United States. In previous decades climate change was only occasionally mentioned outside of scientific circles, but in the late $1980 \mathrm{~s}$, the public and policymakers emerged from the periphery to positions of prominence in global climate change discussions in part because of the public advocacy of a then little-known scientist.

Although many climate scientists testified before Congress in the late 1980s, taking advantage of the opportune climate conditions of the time, many observed how the Congressional testimony of Dr. James Hansen, a climatologist and computer modeler working at the National Aeronautic and Space Administration's (NASA) Goddard Institute for Space Studies, received significantly more notice than others (Schneider 1990, 195; Wilford 1988, 4; Pomerance 1989, 262-268; Ungar 1992, 491493). Hansen's 1988 testimony effectively garnered the attention of journalists and political elites. During his testimony before the Senate committee on June 23, Hansen announced to the mediated world "with 99 percent confidence" that global warming was a real phenomenon (U.S. Congress 1988, 39). Following Hansen's testimony, Dr. Michael Oppenheimer of the Environmental Defense Fund marveled: "I've never seen an environmental issue mature so quickly, shifting from science to the policy realm almost overnight" (Wilford 1988, 4). Although some scientists were skeptical of his conviction, viewing his claims to be unjustified based on his data, to environmentalists "Hansen became an instant hero" (Stevens 1999, 133). Historian of science Spencer Weart argued that evidence of Hansen's influence has been captured in public opinion polls: In a 1981 poll, when asked whether or not they had heard or read about the greenhouse effect, only 38 per cent of respondents said they had. In a 1989 poll, just after James Hansen helped to thrust climate change into the public spotlight, 79 per cent of respondents indicated they had heard or read about the greenhouse effect (Weart 2003, 156). Over time, Hansen's testimony became an important touchstone for debate as recent scholarly treatments of global climate change history have observed (Christianson 1999, 199; Weart 2003, 156).

Saying Hansen's scientific communication was successful in garnering public attention is relatively uncontroversial; however, attempts to explain why have not yet emerged in scholarly treatments of global climate change. I contend Hansen's 1988 success is rooted in his gradual development of a rhetorical sensitivity to his non-scientist audiences: journalists, policymakers, and the general public. In other 
words, Hansen learned to engage in what rhetorical scholars call the rhetoric of "accommodating science" (Fahnestock 1998; Groenewegen 2002; Pellechia 1997). By comparing Hansen's 1986 and 1987 Congressional testimonies with his more effective 1988 testimony, I show how Hansen accommodated his message to adapt his research to non-scientific audiences given the rhetorical constraints and conditions of the time.

Investigating James Hansen's rhetoric of the late 1980s is warranted not just because he plays an important role in the history of global climate change science dissemination to wider audiences. Hansen's rhetoric also deserves our attention because his case can inform scholarly understanding of the rhetoric of accommodating science, rhetoric aimed at adapting scientific knowledge and information to situated, non-scientific audiences. Jeanne Fahnestock noted in her classic treatment of accommodating science why additional scholarly work in this area of rhetorical theory is needed: "The way information changes as a function of rhetorical situation certainly deserves scholarly scrutiny beyond this preliminary study, for at issue is the machinery and quality of social decision making in an expert-dominated age" (Fahnestock 1998, 346). However, as we will soon discover, the literature on accommodating rhetoric is heavily slanted in favor of examining forensic and epideictic rhetoric while overlooking the role of accommodated rhetoric in deliberative settings.

The remainder of this article is divided into three sections. In the first section I review the rhetoric of accommodating science literature. The second section situates Hansen's testimonials and expertise in the context of late $1980 \mathrm{~s}$ climate science. Third, I examine key rhetorical changes Hansen made between his less successful 1986 and 1987 and his more successful 1988 testimonies; here I discuss both Hansen's written and spoken works in relation to their specific contexts and constraints. As we shall see, Hansen's 1988 success and the rhetorical/political emergence of global warming in U.S. discourse is rooted in Hansen's gradual development of a rhetorical sensitivity to historical conditions, rhetorical constraints, and non-scientist audiences.

\section{The Rhetoric of Accommodating Science}

Science rhetoric accommodated to a non-scientific audience is more than "simply a matter of translating technical jargon into non-technical equivalents" (ibid., 335). The act of accommodation involves audience adaptation as information moves from the technical sphere of science into public circulation. In addition, accommodated science also takes into account changes in rhetorical situations. Based on an analysis of articles in the journal Science and its accommodated counterparts, Fahnestock makes a number of observations about accommodated science. For my purposes here, I wish to focus on two of Fahnestock's observations about accommodation rhetoric that make it more than an issue of translation. First, Fahnestock notes that there is a "genre shift that occurs between the original presentation of a scientist's work and its popularization." 
Second, there is also a change in "statement types" that increases the level of certainty in accommodated science (ibid., 332).

Fahnestock uses Aristotle to explain what she means by a "genre shift" in accommodated science. According to Aristotle, rhetoric can be divided into three different classifications or genres: forensic, deliberative, and epideictic. Forensic rhetoric is concerned with the nature and cause of past events and is typically used in legal venues such as courts. Deliberative rhetoric focuses on debating the best possible future action and is usually used in political settings such as a legislature. Finally, epideictic rhetoric concerns the judgment of praise or blame and is often used in ceremonial settings such as awards banquets and funerals. For Fahenstock, "a case can be made for classifying original scientific reports as forensic discourse," a kind of discourse concerned with establishing the nature and cause of past events, the events being experiments and observations. Accommodations of science rhetoric, however, are "overwhelmingly epideictic; their main purpose is to celebrate rather than validate." The implications of such a shift involve a change in the nature of the content being communicated. When science rhetoric moves from the forensic genre to the epideictic, rhetors "must usually be explicit in their claims about the value of the scientific discoveries they pass along. They cannot rely on the audience to recognize the significance of information" (ibid., 333-334).

The second general observation Fahnestock makes about accommodated rhetoric has to do with the taxonomy of "statement types" in the creation of certainty. Borrowing from Bruno Latour and Steve Woolgar's canonical science studies work Laboratory Life: The Construction of Scientific Facts, Fahnestock argues that accommodated science rhetoric uses statement types different from the original, unaccommodated science discourse. Thus, there is a significant change in content. According to Latour and Woolgar, there are five basic statement types that are used in the production of scientific papers. These statement types differ based on the amount of uncertainty expressed by the rhetor. A type five statement "corresponds to a taken-for-granted fact," thus having the highest degree of certainty (Latour and Woolgar 1986, 76). These statements are often free of references and seem self-evident to audiences. A type four statement is less certain than a type five statement. The claim being advanced is often uncontroversial, but it is stated in such a way that the claim is made explicit. Type three and two statements introduce uncertainties into the rhetoric because they contain "hedges, qualifications, or 'modalities' that suggest the information is not indisputable" (Fahnestock 1998, 343; Latour and Woolgar 1986, 77). A type three statement contains subtle elements that could decrease the level of certainty one has in a rhetor's claims. For example, a type three statement might contain a citation, a rhetorical feature that suggests the claim needed evidentiary support. A type two claim contains qualifications that are much stronger. For example, wording that suggests something "may," "might," or "could be" true would detract from a statement's level of certainty. Finally, a type one statement is uncertain, speculative, and openly insufficient.

Based on Latour and Woolgar's taxonomy, Fahnestock concludes that accommodated science rhetoric "traffics in statements of type 5 and 4, the exposed 
certainties, and of type 1, the weakly supported and speculative" (Fahnestock 1998, 334). In accommodated rhetoric, space and time constraints often leave "no room for the qualifications a more knowledgeable audience would demand, qualifications that show the author's awareness of the criticism and refutation that an expert audience could raise" (ibid., 338). Thus, without fear of being challenged by non-scientific audiences, authors of accommodated rhetoric appear more certain because modalities and hedges have been eliminated. In addition, accommodated rhetoric has the tendency to "replace the signs or data of an original research report with the effects or results." In other words, questions of method and observational practice become secondary to the scientific discovery. This emphasis on the product of science, and not the process, allows rhetors to increase "the significance and certainty of their subject matter" (ibid.). When audiences are unaware of uncertainties in scientific methodology, the conclusion appears more certain than it may actually be.

Scholars concerned with the roles of hedging and scientific uncertainty in technical and popular discourse concur with a number of Fahnestock's observations. Most hedging scholars agree that "hedging is the accepted practice in the scientific community" (Horn 2001, 1087). According to Hyland, scientists' attempts to qualify their claims through rhetorical devices such as hedging are "crucial to the procedures of argumentation and claim acceptance, playing a critical role in both the social ratification of knowledge and the system of professional rewards and recognition that emanate from publication" (Hyland 1996, 278). By qualifying one's arguments, scientists engage in the paradoxical practice of weakening their claims rather than actually strengthening them for a particular audience.

Despite their heavy use in scientific texts written for scientific audiences, scholars have also observed that qualifiers, hedges, and modalities are often omitted as the arguments are accommodated for the general public. According to an early study by James Tankard Jr. and Michael Ryan (1974), scientists felt journalists often left out relevant information about methodology (over 35 per cent of the time) and qualifications (over 31 per cent of the time). Eleanor Singer's study likewise found that journalists had "omitted some qualifying statements" in 60 per cent of their stories and "consistently omitted discussion of the research methods" (Singer 1990, 109-110). It seems clear that when journalists accommodate scientific rhetoric for the general public, key rhetorical features, such as "contextual factors and methodological details, are still frequently omitted" (Pellechia 1997, 61).

Although content analyses have verified that accommodated rhetoric contains fewer caveats and qualifiers than the original scientific texts, other studies have examined what effect these uncertainty-adjusting devices have on audience reception of messages. Early writing texts and studies on the effects of hedging suggest hedging should be avoided at all costs, calling these rhetorical devices "weakeners," "downtoners," and "understatements" (Crismore and Vade Kopple 1988, 184-185). Early sociological treatments often assumed these uncertainty devices harmed a scientist's credibility and detracted from "the public image of science" (Zehr 1999, 9). In other words, 
the presence of uncertainty in one's arguments is a kind of "powerless" language (Jensen 2008, 348). However, recent research has reversed this trend. Examining student learning, Avon Crismore and William Vande Kopple found that "subjects who made the greatest learning gains were not the control subjects, those who read passages without hedges. Rather, they were those who read passages with hedges" (Crismore and Kopple 1988, 198). Jakob Jensen (2008), in his study on news coverage about cancer research, found that articles with caveats, limitations, and hedges actually enhanced perceptions of trustworthiness for both the journalists writing the story and the scientists who were addressing the uncertainties. Ultimately, many scholars have concluded that the appropriateness and effectiveness of hedges, qualifications, and caveats is a matter of context, purpose, and audience (Crismore and Vande Kopple 1990, 57; Jensen 2008, 362).

When turning to the accommodated science literature, a great deal has been discovered. Scholars have determined that texts written primarily for scientists by other scientists are more likely to have what Latour and Woolgar would call type two and three statements, statements that are heavily hedged or qualified. There is also ample evidence to suggest accommodated rhetoric written by journalists is not heavily hedged, using what Latour and Woolgar would call type four and five statements. These observations mesh nicely with Fahnestock's observations about the nature of accommodated rhetoric. However, returning to Fahnestock's claims also allows us to observe areas in the literature that have not yet been fully addressed. If non-accommodated scientific texts (i.e., journal articles) can be argued to fit into a forensic genre and accommodated scientific texts (i.e., news stories) are said to fit into an epideictic genre, what have scholars discovered about accommodated rhetoric in deliberative settings? Unfortunately, the answer to this question is "very little." If the use of hedging depends so heavily on context, purpose, and audience, not discussing the use of accommodated rhetoric in deliberative settings (i.e., scientists testifying before Congress) remains a glaring scholarly omission. Does hedging in deliberative settings (where policymakers are concerned with making a decision about future action) function the same way as hedging does in the learning scenarios observed by Crismore and Vande Kopple? Should a perceived sense of urgency on the part of policymakers influence a scientist's decision to accommodate his or her rhetoric? By turning to James Hansen's 1980s testimonials, this article provides scholars with a case study that offers answers to these questions. However, before turning to the actual testimonials, a few contextual comments about James Hansen and the time period are in order.

\section{James Hansen and the Scientific Testimony of the Late 1980s}

James Hansen did not begin his career as someone interested in earthly global warming. Instead, his interests were focused more on other planets. A longtime resident of Denison, Iowa, Hansen received his Ph.D. from the University of Iowa in 1967. 
Writing his dissertation on the climate of Venus under the tutelage of the accomplished astronomer and physicist James Van Allen, Hansen later accepted a position working on NASA's Venus Project. When he accepted a job at NASA's Goddard Institute, he met Dr. Steven Schneider, who introduced to Hansen the possibility of global climate change on Earth. Taking an interest in the subject, Hansen resigned his position on the Venus Project to put all his efforts into developing and testing a computer model of the Earth's climate.

Hansen became one of the first scientists to develop an initial computer model that linked increasing global warming gases to temperature change. Hansen and others noted that the temperature of the Earth would most likely increase approximately $3^{\circ} \mathrm{C}$ in the twenty-first century (Pomerance 1989, 260). However, scientific acceptance of Hansen's ideas was mixed at the time. This reaction was expected given the number of scientists in the 1970s who claimed that the Earth could go into another ice age. Hansen knew that few scientists were willing to say the global warming issue was settled. However, ice drilling in Greenland and Antarctica during the early 1980s further solidified Hansen's belief about the threat of global climate change. In the late 1980s, spurred by extreme weather conditions, Congress invited Hansen to participate in a number of hearings aimed at advising lawmakers about future directions for environmental policy.

Hansen participated in three hearings that framed global warming for the general public and policymakers. Consistent with standard Senate hearing practices, each day of hearings had anywhere from six to twelve witnesses testifying to Senators who were entering and leaving the hearings as their schedules dictated. No panel was made up of more than six people. Each witness presented a summary of his or her written statements that were made accessible to the Senators well before the witnesses actually spoke. Before these hearings, few scientists had testified in Congress on global climate change and few policymakers had thought it serious enough to warrant their attention. The first set of statements and summaries was given before the Senate subcommittee on environmental pollution (a subcommittee of the committee on environment and public works) on June 10 and 11, 1986. Chaired by Senator John H. Chafee of Rhode Island, this hearing was convened to address both ozone and global climate change issues (U.S. Congress 1986). The second collection of texts comes from statements and summaries given before the Senate committee on energy and natural resources on November 9 and 10, 1987. Chaired by Senator Tim E. Wirth of Colorado, this hearing was convened largely due to the momentum generated by the first hearing, as well as scientific concerns about an increasingly bleak future (U.S. Congress 1987). Once again, Hansen was invited to testify; but this time, global climate change was the only issue dominating the discussion. The final texts consist of the statements and summaries given before the Senate committee on energy and natural resources on June 23, 1988. Although the hearing was to be chaired by Senator J. Bennett Johnston of Louisiana, the duties were yielded to Senator Wirth. Thus, Hansen, along with a few other witnesses, was a familiar face to policymakers and activists alike (U.S. Congress 1988). 


\section{Hansen's Rhetorical Accommodations}

Studying Hansen's three testimonies of the late 1980s gives science communication scholars an opportunity to observe rhetorical changes made by a scientist speaking to policymakers. Hansen's three testimonies reveal a historically positioned scientist whose rhetoric improved as he further understood the complexity of his circumstances. Every change Hansen made for his 1988 testimony illustrates his growth as a rhetor cognizant of his situation, a rhetor who accommodated his science to his non-scientific audience. Hansen's accommodations created the conditions necessary for him to gain the support of prominent politicians and the attention of influential journalists.

In 1986, Hansen's speech contained few elements of accommodation; instead, Hansen's rhetoric featured commentary on scientific methodology and the remaining uncertainties in climate change science. Hansen began his speech by noting, "In my brief summary this morning, I cannot describe the capabilities and limitations of climate models in detail. But let me just say a few words about that before turning to predictions of where our climate is heading" (U.S. Congress 1986, 18). The two-point structure of his speech is clear. However, in both his speech and written statement, the primary emphasis was not on his findings, but on the method he was developing to arrive at findings.

More important than Hansen's decision to start with methodological considerations was the confusion that ensued due to information overload about his climate models. This can be seen in the following exchange between Hansen and Senator Chafee:

Chafee: Don't go too fast. Let's make sure we understand what is what in these. What are you showing here?

Hansen: Let me say, first of all, these calculations were carried out by the Climate Modeling Group at the Goddard Institute for Space Studies. The model simulation begins in 1958, when $\mathrm{CO}_{2}$ began to be measured accurately, and the model includes climate forcing due to measured changes in $\mathrm{CO}_{2}$, trace gases, and stratospheric aerosols for the period from 1958 to 1985 .

For the future, we assume two scenarios. In scenario A, we used the current growth rates for $\mathrm{CO}_{2}$ and trace gases. In scenario $\mathrm{B}$, we used growth rates which drop off rapidly as we go into the future. This map shows the global warming in scenario A; that is, for the current growth rates of $\mathrm{CO}_{2}$ and trace gases.

This map shows the global warming trend in the $1990 \mathrm{~s}$ as compared to 1958. The scale for the warming in most of the United States is about $1 / 2{ }_{2}^{\circ} \mathrm{C}$ to $1{ }^{\circ} \mathrm{C}$, the patched green color. You cannot trust the detailed geographical patterns of this predicted warming because of natural climate variability. In fact, if you run the model twice, the detailed patterns will change from one run to another. But note that 
there are similar warmings, warmings of similar magnitude, at other regions at the same latitude as the United States.

So the magnitude of the warming is a firm model prediction, given the assumptions that are in the model. A principal assumption is that the sensitivity of the climate system is $4^{\circ} \mathrm{C}$ for doubled $\mathrm{CO}_{2}$.

Chafee: Wait; let's finish this graph. What is the green? How many degrees in change? (Ibid. 19-20)

Although Hansen was attempting to make his scientific points about warming, listeners had difficulty following his explanation. When prompted to not "go too fast," Hansen bolstered his credibility and defended the results through an invocation of authority by referencing the Climate Modeling Group at the Goddard Institute for Space Studies. However, this did little to explain to Senator Chafee and others what it was they were seeing. Hansen's introduction of commentary about when the data was collected, use of technical vocabulary such as "climate forcing" and "trace gas," uncertainty-creating statements such as "you cannot trust the detailed geographical patterns," and choice to put all of this information into conversation with computer modeling efforts, proved to be too much for many of the Senators. Hansen's decision to emphasize how he arrived at his conclusions, rather than emphasizing the conclusions first, contributed to the creation of uncertainty in 1986.

Hansen also increased the amount of uncertainty surrounding his predictions and models in 1986 by placing hedges, qualifications, and modalities in close proximity to the claim he was trying to make:

But I believe that climate models are good enough now to give us some strong indications about the nature of climate changes which will occur because of the increasing $\mathrm{CO}_{2}$ and trace gases, although a number of qualifications and caveats must accompany the results, especially for the regional and the local scales, as I discussed in my written testimony. (Ibid., 29)

In this excerpt, the introduction of uncertainty complicates one's confidence in the claim that "models are good enough now" if there are still a number of "qualifications and caveats." Declarations such as this one put Hansen's testimony on shaky grounds for audience members. If the policymakers sought legislative guidance about the issue or wished to influence public opinion, Hansen was not making this easy for them. In his written statement, Hansen highlighted the idea of uncertainty in a variety of places. Referring to his climate models, Hansen pointed out that when it came to some regional predictions, such as foreseeing patterns of precipitation, the models were "not sufficiently realistic" (ibid., 81). He also pointed out how representations of ocean currents in climate models were "not sufficiently realistic to predict such phenomenon" (ibid.). Despite Hansen's conclusion in his 1986 written statement that "evidence confirming the essence of the greenhouse theory is already overwhelming," the bulk of his written statement reads more like a technical report designed to inform 
readers about what a climate model is, how it works, and what its limitations are, rather than a statement offering conclusions from the actual use of the model. Hansen appeared to be locked into a technical style that privileged what Gross calls the "suite of methods" one could use to discover the material truths of the world (Gross 1996, 85). Overall, then, Hansen's speech and written testimony in 1986 featured questions of method as much as conclusions and were filled with uncertainty-producing statements, hedges, and modalities. Hansen's 1986 speech did little to break away from what Fahnestock would consider to be a non-accommodated from of scientific rhetoric.

Hansen's 1987 speech contained a number of similarities to the 1986 speech. In terms of organization, Hansen's 1987 speech lacked a preview, but this is not to say it was unorganized. Instead, audience members heard a one-sentence thesis: "I will summarize the result of numerical simulations of the greenhouse effect, carried out with colleagues at the Goddard Institute" (U.S. Congress 1987, 51). Although this sentence implies Hansen was going to feature his "result," this ended up not being the case. As with his 1986 statement, Hansen's 1987 statement more prominently featured the methodology and uncertainties rather than his conclusions.

In 1987, Hansen once again made early and significant use of the A and B models with no results to show for it. One-third of the way into his speech, Hansen announced which model he believed was the most likely scenario: "These scenarios are designed specifically to cover a very broad range of cases. If I were forced to choose one of these as most plausible, I would say Scenario B. My guess is that the world is now probably following a course that will take it somewhere between A and B" (ibid., 51). Despite Hansen's belief that these models were of the utmost importance, and the obvious contradiction between "guessing" B is the right model when the world is not moving in that direction, no questions were dedicated to Hansen's models in the question and answer session. Policymakers spent little time trying to decipher the data and models, thus missing one of Hansen's main points: the importance of method.

Although Hansen did less to note the uncertainties in 1987 than he did in 1986, they were still present throughout his discourse. Speaking about the future predictions of his models, Hansen noted that "it is difficult to predict reliably how trace gases will continue to change" (ibid.). But this begs the question, "If you cannot feed reliable variables into your climate models, how can one be sure the models produce reliable results?" Hansen's own observations about the limitations of his models contributed to the creation of uncertainties. These statements reveal Hansen's continued use of modalities. By giving guesses and noting difficulties, Hansen's testimony starts to feature what Fahnestock, Latour, and Woolgar would call type two statements, statements heavily hedged or qualified to the point of uncertainty.

In addition to Hansen modifying the strength of his claims, others also contributed to the sense of uncertainty. On the second day of speeches, Clarence Brown, Deputy Secretary of Commerce, provided testimony that was nothing short of a defense of the status quo. He stated, "while experiments project an average global warming due to increased carbon dioxide, no direct climate change due to increased carbon dioxide 
has been confirmed" (U.S. Congress 1987, 160). Brown also referenced the cooling in temperature that took place from about 1940 to 1970. William Graham, Deputy Administrator at NASA, also contributed to the uncertainty in 1987 in an exchange with Senator Stafford:

Stafford: Now, let me be the devil's advocate here for just a minute because one of the witnesses this morning testified that between 1940 and 1970 the globe was in a cooling trend, and that had to have been during a period of very high use of both coal and other fossil fuels, and that from 1970 to the present there is undoubtedly a warming trend, which may also be the result of greenhouse effect.

My question is: Could some other factor have influenced the cooling trend from 1940 to 1970, and could it have been the Sun, for example, or would you have any comment on that?

Graham: Yes; Senator Stafford. I think this illustrates the fact that we don't fully understand the mechanisms that drive the climate of the Earth or the interaction of a number of the phenomena that we observe today on the climate and on other parts of the environment. (Ibid., 171)

What Graham was pointing out when he mentioned "mechanisms that drive the climate of the Earth," were some of the mechanisms Hansen mentioned in 1986, such as the role of oceans in the transfer of heat. Similar to the 1986 hearing, the 1987 hearing produced little attention.

Both Hansen and Wirth were aware that the earlier hearings had failed to arouse the kind of interest and attention that was needed to push global climate change onto the front burner of congressional politics. They were also aware that something needed to change. In conversations with Wirth, Hansen suggested maximizing the possibility of success by timing the speech to coincide with weather conditions that would be more amenable to a general audience. Although the 1986 hearing was held in June, a time of the year that seemed right for Hansen, the 1987 hearing was held on a rainy day in November. According to William K. Stevens, Hansen argued after his 1987 testimony that "people would pay attention to global warming only if the hearing were held in the summer, when it was hot" (Stevens 1999, 131). The selection of a June hearing was not accidental; Hansen was deliberately attempting to create conditions for rhetorical success. According to Weart, Wirth agreed to hold the 1988 hearing during June once again, despite the summer being "hardly a normal time for politicians who sought attention" (Weart 2003, 155). Wirth also aided Hansen in creating better conditions for success by altering the order of speakers on the day Hansen was scheduled to testify. According to Stevens, "Wirth told Hansen that he was shifting the order of testimony so that Hansen could go first, in case the television cameras left early" (Stevens 1999, 132). Hansen's rhetoric benefited from the favorable conditions leading up to the 1988 hearing: the summer of 1988 was one of the hottest on record, Wirth changed the order 
for Hansen to be featured first, and, most importantly, Hansen finally accommodated his rhetoric to his audience.

In 1988, Hansen used a very concise style and organization. Consistent with what Fahnestock has noted about accommodated science, Hansen began with his conclusions instead of methodological concerns. After thanking the Chairman for allowing him to testify, Hansen then immediately said the following:

I would like to draw three main conclusions. Number one, the earth is warmer in 1988 than at any time in the history of instrumental measurements. Number two, the global warming is now large enough that we can ascribe with a high degree of confidence a cause and effect relationship to the greenhouse effect. And number three, our computer climate simulations indicate that the greenhouse [e]ffect is already large enough to begin to effect the probability of extreme events such as summer heat waves. (U.S. Congress 1988, 39)

Similarly, in the second paragraph of his written, prepared statement that was circulated to the Senators, Hansen wrote:

My principal conclusions are: (1) the earth is warmer in 1988 than at any other time in the history of instrumental measurements, (2) the global warming is now sufficiently large that we can ascribe with a high degree of confidence a cause and effect relationship to the greenhouse effect, and (3) in our computer climate simulations the greenhouse effect now is already large enough to begin to affect the probability of occurrence of extreme weather events such as summer heat waves; the model results imply that heat wave/drought occurrences in the Southeast and Midwest United States may be more frequent in the next decade than in climatological (1950-1980) statistics. (Ibid., 43)

Comparing these two excerpts illustrates Hansen's dedication to having his spoken testimony remain consistent with his written statement. In addition, Hansen's mention of "extreme weather events such as summer heat waves" while the summer of 1988 burned its way into American memory was not coincidental. He adapted his rhetoric to those conditions without making the unscientific claim (at the time) that 1988 was causally related to global climate change. Hansen also shows signs of being a seasoned public speaker through his decision to omit extraneous details related to his claim. Although his written testimony provides more details, such as specific regions of the nation (the Southeast and Midwest) that were breaking temperature records, Hansen chose to leave this information out of his speech. The end result was that the claims were easier for audiences to digest.

In 1988, Hansen again mentioned computer models, but his discussion created less confusion than in 1986. This was, in part, due to the clear and unambiguous statements Hansen made about his level of certainty in the scenarios. But more importantly, Hansen related what he was showing on his viewgraphs to real world conditions for the first time in the three years. For example: 
My first viewgraph ... shows the global temperature over the period of instrumental records which is about 100 years. The present temperature is the highest in the period of record. The rate of warming in the past 25 years, as you can see on the right, is the highest on record. The four warmest years, as the Senator mentioned, have all been in the 1980 s. And 1988 so far is so much warmer than 1987, that barring a remarkable and improbable cooling, 1988 will be the warmest year on record. (Ibid., 39)

For the lay listeners at the hearings, Hansen's presentation was much clearer in 1988 than in 1986 or 1987. The inclusion of weather conditions that policymakers were living through made the presentation of temperature charts and computer simulations more palatable, while starting with his conclusions made his testimony easier to understand. If the message Hansen was delivering in the early years was perceived as muddled and confused, his 1988 testimony seemed crystal clear.

The level of uncertainty found in Hansen's 1988 testimony also differed significantly from earlier years. Although Hansen still wanted to understand some of the processes that were unclear to him, he only dedicated one sentence to that issue in his 1988 speech: "Finally, I would like to stress that there is a need for improving these global climate models, and there is a need for global observations if we're going to obtain a full understanding of these phenomena" (ibid., 41). This sentence's placement at the end of Hansen's testimony gives it the appearance of being more of an afterthought than an important point in his presentation. In addition, the language itself makes it seem as though the additional improvements he is referring to are part of a natural progression associated with scientific work rather than limitations associated with the current state of knowledge. In his written testimony, the idea of uncertainty comes up in a few additional instances, but it is not enough to detract from the weight of his argument. For example, Hansen noted that there were "major uncertainties" in his climate models due to "global climate sensitivity" and "heat uptake and transport by the ocean," but he concludes this section of his written statement with an overwhelmingly certain declaration: "Global warming has reached a level such that we can ascribe with a high degree of confidence a cause and effect relationship between the greenhouse effect and the observed warming" (ibid., 44). The notion of uncertainty is present in Hansen's 1988 testimony, but is significantly downplayed. Add to this Hansen's continuous use of clear and certain language throughout his presentation, and an audience is much more likely to see Hansen's request for additional research as an attempt to further refine an already decided matter. Hansen's comments about the "clear signs of the greenhouse effect," the "clear tendencies" in the data, the observation of a "very strong case," as well as changes "large enough to be noticeable to the average person" minimize any uncertainty creation the last sentence of his presentation may have displayed (ibid., 40-41).

When examining Hansen's 1986, 1987, and 1988 speeches and written statements, definite signs of rhetorical accommodations emerge from his 1988 rhetoric, accommodations attributable to Hansen's growth as a rhetor responding to his given 
constraints. First, Hansen, aided by Wirth, attempted to create the conditions that would improve his chances of success. Second, Hansen did more to emphasize his conclusions rather than his method. Third, Hansen reduced the number of hedges, qualifications, and modalities that would have created a sense of uncertainty. The rhetoric of the late $1980 \mathrm{~s}$ indicates Hansen was a rhetor who came to terms with his situation: Hansen became a better rhetor as he learned from his previous experiences and accommodated his rhetoric accordingly.

\section{Conclusion}

This article has explored why Hansen is recognized as a key scientist in the global climate change debates of the late 1980s: his rhetoric of accommodated science was positioned in a favorable environmental and rhetorical situation. In the end, can Hansen's testimony be said to be the only reason for the increase in policymakers' concerns or the increased media coverage of environmental issues? No. Weather conditions, political interests, and other external circumstances certainly contributed to Hansen's success and constrained his available rhetorical options. However, the success of Hansen and his rhetorical choices are difficult to deny. A search of the Lexis-Nexis database for news stories that mention Hansen adds support to this claim. Before 1988, Hansen's speeches about climate change were virtually ignored. The Washington Post published one article on his 1986 testimony and was silent in 1987 (Peterson 1986). The New York Times published one article on a speech Hansen delivered in 1982, but nothing for his 1986 or 1987 testimonials (Anon. 1982). But 1988 was significantly different. The Washington Post quoted directly from Hansen's testimony that, "The greenhouse effect has been detected and it is changing our climate now" (Weisskopf 1988, A4.) The New York Times not only featured Hansen in a front page article, quoting from his speech multiple times, but it also featured a line from him in the "Quotation of the Day" section of the paper (Shabecoff 1988a). Articles referencing Hansen's speech also appeared in August and December, months after he had delivered it (Wilford 1988; Shabecoff 1988b). Even international newspapers, such as London's The Times, featured stories on his testimony (Binton 1988). Furthermore, attention to Hansen's speech was not isolated to newspapers. According to Stephen Schneider, Hansen's claims amassed an impressive amount of press coverage across a variety of media outlets: "Jim appeared on a dozen or more national television programs, was quoted in a front-page story in the New York Times, and even showed up on David Brinkley's Sunday television program sporting a large pair of dice on which he painted some faces to represent more warm years" (Schneider 1990, 195). Through a number of rhetorical adjustments in a fortunate set of circumstances, Hansen managed to use his testimony to thrust global climate change issues into the public spotlight. Initially, my analysis has illustrated one way scientists can, and do, develop a rhetorical sensitivity in light of their rhetorically constrained situations. James Hansen did not simply get lucky 
in 1988; he accommodated his rhetoric to maximize its effectiveness by emphasizing conclusions rather than method and by reducing the use of qualifications, hedges, and modalities.

My analysis also contributes to our understanding of accommodated rhetoric in deliberative settings. As Hansen encountered a change in genre from the forensic to the deliberative, his rhetoric was accommodated in such a way that hedges and modalities were downplayed in favor of featuring his findings. This case study offers one example of how accommodated science rhetoric functions in the deliberative sphere of politics, an area Fahnestock noticeably omitted in her classic treatment of the subject. This essay also suggests accommodated rhetoric functions effectively in situations where policymakers are faced with a sense of urgency. However, scientists who choose to accommodate their rhetoric to non-scientist audiences should be cautious when speaking to policymakers in similar situations. As questions of method are replaced with claims of certainty, scientists run the risk of overstepping their bounds of expertise as they are asked to move from being technical advisors to being legislative authors. Hansen encountered this very issue. When Senator Chafee asked Hansen what he would do about the global warming problem if he were made king, Hansen answered, "I am sorry if I sound more like a befuddled scientist rather than a king, but I would like to understand the problem better before I order any dramatic actions" (U.S. Congress 1986, 29). Hansen's response was simply to maintain his scientist persona, a refusal to step outside of the very persona that generated his credibility to begin with.

Crafting his testimonies in the late 1980s was certainly no simple charge; but, Hansen has shown he was up to the task and that this kind of communication could be accomplished with success. Troubled by skeptics who revisit his 1988 claims in order to shed doubt on the realities of global climate change, James Hansen posted a short commentary on the Goddard Institute for Space Studies' website. Reflecting on his experiences as a scientist who often communicates with non-scientist audiences, he said: "But one quickly learns that such communication is not easy, at least not for many of us" (Hansen 1999). Indeed, a great deal is left to be understood about scientific accommodations in deliberative settings before they can be classified as comfortable rhetorical practices.

\section{References}

Anon. 1982, January 7. "Warming of World's Climate Expected to Begin in the 80's." New York Times, B14.

Anon. 1988, July 26. "Flames Now Expected to Bypass Old Faithful; The Blaze has Charred about 40,000 Acres." New York Times, A18.

Binton, Michael. 1988, June 25. "Earth Warming Trend; Heat Wave and Drought in US Caused by 'Greenhouse Effect'; Dr. James Hansen.” The Times.

Christianson, Gale. 1999. Greenhouse: The 200-year Story of Global Warming. New York: Penguin Books.

Crismore, Avon, and William J. Vande Kopple. 1988. "Readers' Learning From Prose: The Effects of Hedges." Written Communication 5:184-202. 
Crismore, Avon, and William J. Vande Kopple. 1990. "Rhetorical Contexts and Hedges." Rhetoric Society Quarterly 20:49-59.

Fahnestock, Jeanne. 1998. "Accommodating Science: The Rhetorical Life of Scientific Facts.” Written Communication 15:330-350.

Groenewegen, Peter. 2002. "Accommodating Science to External Demands: The Emergence of Dutch Toxicology." Science, Technology, \& Human Values 27:479-498.

Gross, Alan G. 1996. The Rhetoric of Science. Cambridge: Harvard University Press.

Hansen, James. 1999. "The Global Warming Debate." http://web.archive.org/web/20010223232940/ http://www.giss.nasa.gov/edu/gwdebate/ (last accessed September 19, 2012).

Horn, Kelly. 2001. "The Consequences of Citing Hedged Statements in Scientific Research Articles." BioScience 51:1086-1093.

Hyland, Ken. 1996. "Talking to the Academy: Forms of Hedging in Science Research Articles." Written Communication 13:251-281.

Jensen, Jakob D. 2008. "Scientific Uncertainty in News Coverage of Cancer Research: Effects of Hedging on Scientists' and Journalists' Credibility." Human Communication Research 34:347-369.

Latour, Bruno, and Steven Woolgar. 1986. Laboratory Life: The Construction of Scientific Facts. Princeton: Princeton University Press.

Pellechia, Marianne G. 1997. "Trends in Science Coverage: A Content Analysis of Three U.S. Newspapers." Public Understanding of Science 6:49-68.

Peterson, Cass. 1986, June 11. “A Dire Forecast for 'Greenhouse' Earth.” Washington Post, A1.

Pomerance, Rafe. 1989. "The Dangers from Climate Warming: A Public Awakening." In The Challenge of Global Warming, edited by Dean E. Abrahamson, 259-269. Washington DC: Island Press.

Schneider, Stephen. 1990. Global Warming: Are We Entering the Greenhouse Century? New York: Vintage Books.

Shabecoff, Philip. 1988a, June 24. "Global Warming has Begun, Expert Tells Senate." New York Times, A1.

Shabecoff, Philip. 1988b, December 7. "Ferocious Storms and Drought Seen." New York Times, A25.

Singer, Eleanor. 1990. "A Question of Accuracy: How Journalists and Scientists Report Research on Hazards." Journal of Communication 40:102-116.

Stevens, William K. 1999. The Change in the Weather. New York: Random House.

Tankard, James W., and Michael Ryan. 1974. "News Source Perception of Accuracy of Science Coverage." Journalism Quarterly 51:219-223.

Ungar, Sheldon. 1992. "The Rise and Relative Decline of Global Warming as a Social Problem." Sociological Quarterly 22:483-501.

U.S. Congress. Senate. Subcommittee on Environmental Pollution. 1986. Ozone Depletion, the Greenhouse Effect, and Climate Change: Hearing before the Subcommittee on Environmental Pollution, $99^{\text {th }}$ Cong. Washington DC: U.S. Government Printing Office.

U.S. Congress. Senate. Committee on Energy and Natural Resources. 1987. Greenhouse Effect and Global Climate Change: Hearing before the Committee on Energy and Natural Resources, $100^{\text {th }}$ Cong., $1^{\text {st }}$ sess. Washington DC: U.S. Government Printing Office.

U.S. Congress. Senate. Committee on Energy and Natural Resources. 1988. Greenhouse Effect and Global Climate Change: Hearing before the Committee on Energy and Natural Resources, $100^{\text {th }}$ Cong., $2^{\text {nd }}$ sess. Washington DC: U.S. Government Printing Office.

Weart, Spencer. 2003. The Discovery of Global Warming. Cambridge: Harvard University Press.

Weisskopf, Michael. 1988. "Scientist Says Greenhouse Effect Is Setting in." Washington Post, A4.

Wilford, John N. 1988, July 23. "His Bold Statement Transforms the Debate on Greenhouse Effect." New York Times, C4.

Zehr, Stephen C. 1999. "Scientists' Representations of Uncertainty.” In Communicating Uncertainty: Media Coverage of New and Controversial Science, edited by Sharon M. Friedman, Sharon Dunwoody, and Carl L. Rogers, 3-22. Mahwah NJ: Lawrence Erlbaum. 